\title{
Effect of Organic and Inorganic Seed Treatments on Germination, Yield and Yield Attributing Characters in Brinjal (Solanum melongena L)
}

\author{
Kalyan Singh Seervi ${ }^{1 *}$, Bineeta M. Bara ${ }^{1}$, Abhinav Dayal ${ }^{1}$ \\ Praveen Choyal ${ }^{2}$ and Shankar Lal Yadav
}

${ }^{1}$ Department of Genetics and Plant Breeding, ${ }^{2}$ Department of Horticulture, ${ }^{3}$ Department of Soil Science, Sam Higginbottom University of Agriculture Technology and Sciences, Allahabad (U.P), India

*Corresponding author

\section{A B S T R A C T}

Keywords

Brinjal, Seed treatment, Yield, Pre-sowing.

Article Info

Accepted:

10 June 2018

Available Online:

10 July 2018
A field experiment was conducted during kharif season 2017 at field experiment, Department of Genetics and Plant Breeding, Naini Agricultural Institute, SHUATS, Allahabad (U.P.) to study the effect of organic \& inorganic seed treatments on germination and yield \& yield attributing characters in Brinjal (Solanum melongena L.). The field experiments were laid out in a Randomized Block Design. All pre-sowing treatments recorded significantly higher growth and yield parameters over control. However, GA3 $(100 \mathrm{ppm})$ recorded significantly higher plant height $(\mathrm{cm}) 32.58$ and 60.65 at 30 DAT and 75 DAT, fruit yield (first Picking) 18.41 t/ha than the other pre-sowing treatments except $\mathrm{ZnSO} 4(10 \%)$ and Cow Urine $(20 \%)$. Similarly growth and yield components were significantly higher in GA3 (100ppm) whereas control recorded significantly lower growth and yield parameters.

\section{Introduction}

Brinjal (Solanum melongeena L.) commonly know as egg plant, belongs to the family Solanaceae and referred by different names, viz., egg plant, aubergine, garden egg (French), baigan (Hindi), badanekai (Kannada), vangi (Marathi) and vankaya (Telugu). Brinjal is an important vegetable crop grown in India throughout the year. India is regarded as the center of origin of brinjal (Vavilov, 1931). Contrary to the common belief, it is quite high in nutritive value and can be well compared with tomato. Brinjal fruit contains high amount of Carbohydrates $(6.4 \%)$, Protein $(1.3 \%)$, Fat $(0.3 \%)$, Calcium $(0.02 \%)$, Phosphorus $(0.02 \%)$, Iron $(0.0013 \%)$ and other mineral matters. Apart from this, it also contains- Carotene (34 mg), Riboflavin (0.05 mg), Thiamine $(0.05 \mathrm{mg})$, Niacin $(0.5$ $\mathrm{mg}$ ) and Ascorbic acid (0.9 mg) per $100 \mathrm{~g}$ fruit (Choudhary, 1976).

The brinjal plant contains an alkaloid called "solanine" found in roots and leaves. Some medicinal use of egg plant tissues and extract 
include treatment of diabetes, asthma, cholera, bronchitis and diarrhea, its fruits and leaves are reported to lower blood cholesterol levels. In dryland agriculture, drought resistance of plant is one of the very important factors to get the higher yield. Though, this is largely depends on genetic makeup of the variety, presowing treatments like hardening also practiced to defy the ill effects of drought on emergence and growth of crop. Pre-sowing treatments have done in order to impart resistance against stress conditions viz., drought and cold to the emerging seedlings (Balamurugan et al., 2003).

Pusa Purple Round was developed at IARI, New Delhi. The plants are very tall with a thick stem of greenish purple colour. Leaves are highly serrated and deep green in colour. Fruits are round with purple colour. Each fruit weighs on an average 130-140g with only 6 fruits per plant, resistant to shoot borer and little leaf disease.

\section{Materials and Methods}

The field experiment for present investigation entitled was conducted during kharif 2017 at field experimentation center, Department of Genetics and Plant Breeding, Naini Agricultural Institute, SHUATS, Allahabad U.P. The experiment consisted of 7 treatments involving one control (without pre-sowing treatment). The site of experiment is located at $25.57^{\circ} \mathrm{N}$ latitude, $81.51^{\circ} \mathrm{E}$ longitude and 98 meter above the sea level. The experiment was laid out in randomized block design with seven treatments replicated thrice. Fresh seeds were soaked in water with required quantity of chemicals and allowed to absorb moisture up to 40 per cent of their weight and kept in imbibed condition for about 24 hours at about $20^{\circ} \mathrm{C}$.

These were then spread out in a thin layer for drying under shade for two to three days, during this period the seeds get dried almost to the original weight, then taken for nursery sowing.

The experiment consisted of 7 treatments involving one control (without pre-sowing treatment). The details of the treatments are given below.

T0: Control

T1:ZnSO4@ 5\%

T2: ZnSO4@10\%

T3: Gibberellic acid@ 50ppm

T4 : Gibberellic acid@ 100ppm

T5 : Cow urine@ 10\%

T6 : Cow urine@ 20\%

\section{Results and Discussion}

In the present study fresh seeds of brinjal seeds (cv. Pusa Purple Round) was given presowing treatment with $\mathrm{ZnSO} 4$ (5\%), $\mathrm{ZnSO} 4$ (10\%), GA3 (100 ppm), GA3 (50 ppm), Cow urine (10\%), Cow Urine (20\%), soakingdrying in addition to various concentration. The treated seeds were evaluated for field performance. The results are discussed here under.

There was remarkable effect on growth parameters under different treatment combination. Field emergence, days to 50\% flowering, plant height $(\mathrm{cm})$, number of fruit per plant, fruit length $(\mathrm{cm})$, fruit girth, fruit weight $(\mathrm{g})$, fruit yield/plant $(\mathrm{kg})$, fruit yield per plot $(\mathrm{kg})$, fruit yield per ha. (t) has shown significant result with the application of different levels $\mathrm{ZnSO} 4$, Gibberellic acid and Cow urine. However maximum plant height (cm) 32.58 and 60.65 at 30 DAT and 75 DAT in treatment T4 (Gibberellic acid@100 ppm). 
Table.1 Effect of pre-sowing seed treatments on field emergence, plant height, days to 50 per cent flowering, and fruit Yield parameters in Brinjal

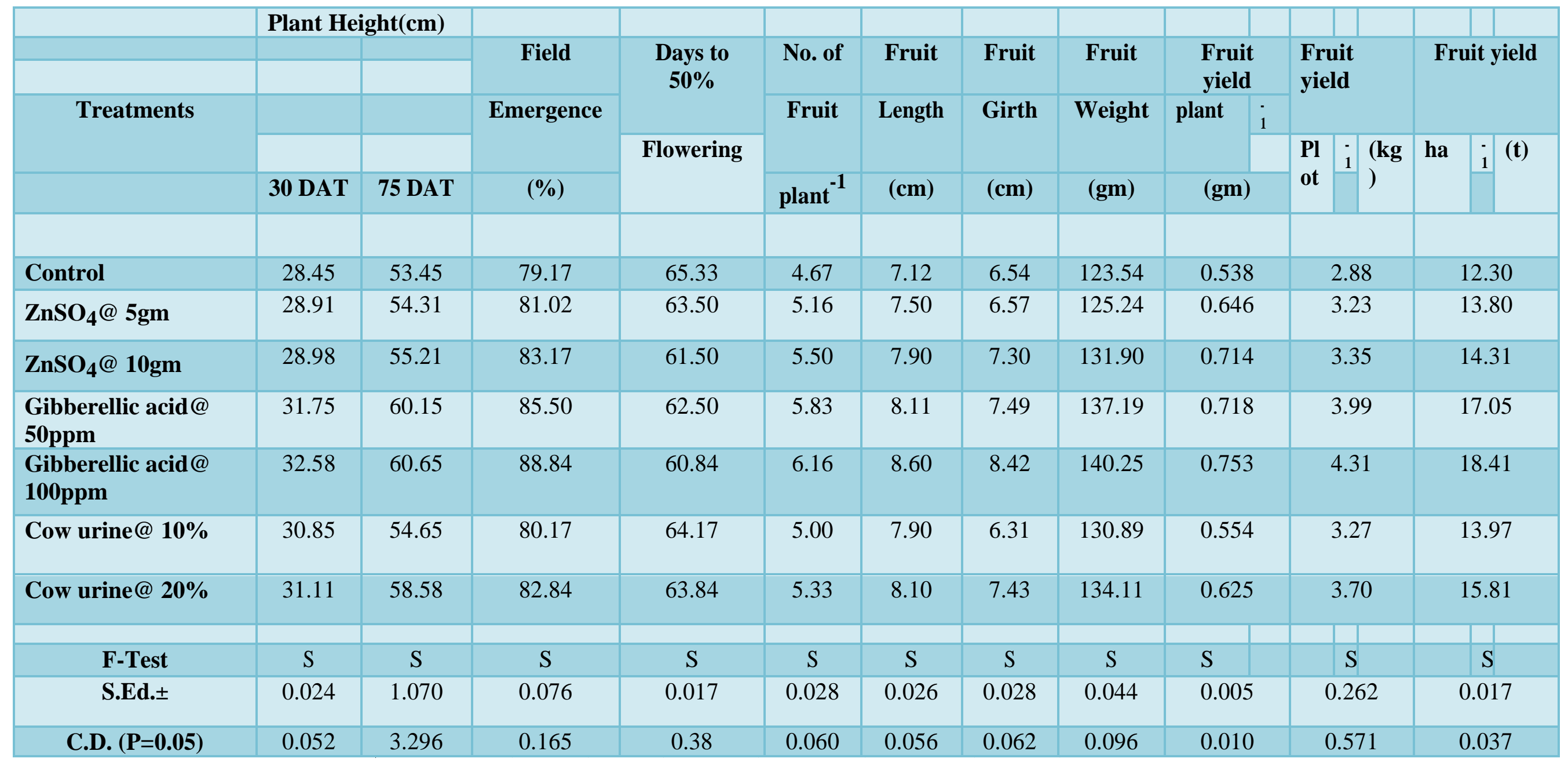


The results are in agreement with Omran et $a l .$, (1980) in okra, Jagadish (1993) in tomato and chilli and Tewari et al., (2001) in onion.

The seed treatment, T3 (GA3 @ 100ppm) was recorded maximum field emergence $(88.84 \%)$ at 15 DAS, days to $50 \%$ flowering (60.84), number of fruit per plant (6.16), fruit length $(8.60 \mathrm{~cm})$, fruit girth $(8.42 \mathrm{~cm})$, fruit weight $(140.25 \mathrm{~g})$, fruit yield $/$ plant $(0.753 \mathrm{~kg})$, fruit yield per plot $(4.31 \mathrm{~kg})$ and fruit yield per ha. (18.41t) followed by (T3) GA3 @ 50ppm. The similar results of higher fruit yield due to presowing treatment with GA3 200 ppm were reported by Jagadish (1993) in tomato, chilli, and onion and Tewari et al., (2001) in onion. The higher fruit yield in pre sowing treatment with GA3 200 ppm may be ascribed to the fact that the plants remained physiologically more active, source to sink relationship in the plant parts and build up sufficient food reserve for developing flowers and fruits. Thus the plants that gave higher fruit yield resulted in higher fruit yield per unit area (Veerabhadra, 2002).

It is concluded form the present study different pre sowing seed treatments showed that significant effect on field emergence, days to $50 \%$ flowering, plant height and yield parameters, treated with (T4) Gibberellic acid@100ppm (Soaking) 24 hours recorded higher and followed by (T3) Gibberellic acid@ 50ppm (Soaking) 24 hours. Gibberellic acid@100ppm (T4) recorded significantly higher field emergence, days to $50 \%$ flowering, plant height, fruit length, fruit girth, fruit weight, fruit yield/plant $(\mathrm{kg})$, fruit yield per plot $(\mathrm{kg})$, fruit yield per ha.(t), it was the best treatment. These conclusions are based on the result of field investigation.

\section{References}

Balamurugan, P., Balasubramani, V. and Sundaralingam, K., (2003). Nutrient
Coating and Foliar Application on Seed Yield and Quality of Sesame. Icar Short Course on Seed Hardening and Pelleting Technologies for Rainfed/Garden Land Ecosystems, Tamil Nadu Agricultural University, Coimbatore. P. 192.

Choudhury, B. (1976). Vegetables (4th Edn.,). National Book Trust, New Delhi, PP. 50-58.

Hore, J.K., Paria, N.C. and Sen, S.K., (1988). Effect of Pre-Sowing Seed Treatment of Germination, Growth and Yield of Onion (Allium cepa L.) Var. Red Globe. Haryana Journal of Horticultural Sciences, 17 (1-2): 8387.

Jagadish, G.V., (1993). Seed storability, ageing and effect of pre-sowing treatment on the performance of some vegetable crops. M.Sc. (Agri.) Thesis, University of Agricultural Sciences, Dharwad.

Kumar, A.V., Dharmalingam, C. and Sambandamurthi, S., (1988). Effect of Pre- Sowing Treatment on Seed Yield and Quality in Bhendi. South Indian Horticulture, 36(3): 118

Kumar, Avdhesh, Singh, Kumar R. and Parmar, A.S. (2012). Effect of Foliar Application of Micronutrients on Yield Characters and Yield of Tomato (Lycopersicon esculentum Mill L). Journal of Multidisciplinary Advance Research. 1(2): 10- 14.

Kumar,K., Basavegowda and Sharnkumar (2014). Effect of Pre-Sowing Treatments on Seed Quality and Field Performance of Brinjal Hybrid cv.Arka Navneet (Solanum melongena L.). International Journal of Agricultural Sciences 10(1): 441-445.

Mitra, R. and Basu, R.N., (1979). Seed Treatment for Viability, Vigour And Productivity of Tomato. Scientia Horticulturae, 11: 365-369 
Omran, A.F., Elbakry, A.M. and Gawish, R.A., (1980). Effect of Soaking Seeds in Some Growth Regulator Solutions on The Growth, Chemical Constituents and Yield of Okra. Seed Science and Technology, 8(2): 161168.

Rao, S., N.K., Bhatt, R.M. and Anithanaren, (2000). Effect of Pre-Sowing Treatment on Germination and Seedling Growth in Capsicum annum (Cv. California wonder) Under Different Moisture Levels. Vegetable Science, 27 (1): 51-53.

Reddy, S.D. and Palaniappan, S.P., (1987). Effect of Seed Soaking on The Performance of Greengram (Vigna radiata L.). Madras Agricultural Journal, 74 (3): 175-176.

Renugadevi, J. and Jacqueline, A., Selvraraj, (1994). Effect of Pre-Sowing Treatment on Germination and Vigour in Bitter Gourd (Momordica charantia L.) cv. Co-1. Seed Research, 22(1): 64-65.

Sharma, A.K., Rattan, R.S. and Pathania, N.K., (1992). Effect of Plant Growth
Regulators on Yield and Morphological Traits in Brinjal (Solanum melongena L.). Agricultural Science Digest, 12: 219-222.

Subbian, P., Srinivasulu, Reddy, D. And Palaniappan, S.P., (1987). Effect of Seed Soaking on the Performance of Greengram (Vigna radiata L.). Madras Agricultural Journal, 74(3): 175-176.

Tawab S., Ayub G., Tawabfaiza, Khan O., Bostan N., Ruby G., Ahmad S. And Afridi Ume-Kalsoom (2015). Response of Brinjal (Solanum melongena L.) Cultivars to Zinc Levels. Arpn Journal of Agricultural And Biological Science. 10(5): 172178.

Tewari, N., Poonam, Singh, C. Lal., Katiyar, P.K. and Vaish, C.P., (2001). Effect of Pre-Sowing Seed Treatment on Germination Growth and Yield of Onion (Allium cepa L.). Seed Research, 29 (2): 238-239.

Vavilov, N.I., (1931). The role of Central Asia in the origin of cultivated plants. Bull. of Appl. Botany.

\section{How to cite this article:}

Kalyan Singh Seervi, Bineeta M. Bara, Abhinav Dayal, Praveen Choyal and Shankar Lal Yadav. 2018. Effect of Organic and Inorganic Seed Treatments on Germination, Yield and Yield Attributing Characters in Brinjal (Solanum melongena L.). Int.J.Curr.Microbiol.App.Sci. 7(07): 1614-1618. doi: https://doi.org/10.20546/ijcmas.2018.707.189 